Edinburgh ; Prof. R. E. Coupland, Department of Anatomy, Queen's College, Dundee; J. A. Crichton, head of the Applied Nutrition Department, Rowett Research Institute, Bucksburn, Aberdeen; Prof. K. W. Donald, Department of Medicine, University of Edinburgh; Dr. W. J. Eggeling, conservation officer for Scotland, Nature Conservancy; Prof. R. B. Fisher, Department of Biochemistry, University of Edinburgh; R. S. Glover, officer-in-charge, Scottish Marine Biological Association's Oceanographic Laboratory, Edinburgh; W. Hutton, deputy-chairman of the South of Scotland Electricity Board; T. R. M. Lawrie, district geologist in charge of Highland work, H.M. Geological Survey, Edinburgh; R. D. Lord, senior lecturer in mathematies, Royal College of Science and Technology, Glasgow ; Dr. J. A. Lovern, head of the Lipids and By-products Section, Torry Research Station, Aberdeen; Dr. D. M. C. MacEwan, lecturer in physics, Queen's College, Dundee; Prof. J. L. Malcolm, Department of Physiology, University of Aberdeen; Prof. J. A. Roper, Department of Geneties, University of Sheffield; Dr. F. A. Rushworth, lecturer in natural philosophy, University of St. Andrews; Dr. J. M. Shewan, head of the Bacteriology Section, Torry Research Station, Aberdeen; Prof. M. G. P. Stoker, Department of Virology, University of Glasgow ; Prof. P. D. Sturkie, Department of Poultry Physiology, Rutgers University, New Brunswick (presently S.P.S.O., Agricultural Research Council Poultry Research Centre, Edinburgh) ; Prof. P.A. Sweet, Department of Astronomy, University of Glasgow ; Prof. W. J. Tulloch, Depart. ment of Bacteriology, Queen's College, Dundee ; Dr. G. B. Warburton, senior lecturer in charge of the Postgraduate School of Applied Dynamics, University of Edinburgh; Prof. P. E. Weatherley, Department of Botany, University of Aberdeen; Dr. R. Westwater, manager, Technical Service Department, Imperial Chemical Industries, Ltd. (Nobel Division).

\section{Royal Geographical Society Awards}

H.M. THE QUEEN has approved the award of the Royal medals of the Royal Geographical Society as follows: Patron's Medal, to Prof. Théodore Monod, director of the Institut français d'Afrique Noire, for geographical exploration and research in the Sahara; F'ounder's Medal, to Phillip G. Law, leader of the Australian National Antarctic Research Expeditions, for Antarctic exploration and research ; Victoria Medals, to Dr. Armando Cortesão, for studies in the history of Portuguese cartography, and Prof. J. A. Steers, University of Cambridge, for research in coastal morphology; Murchison Grant, to Prof. J. Wreford Watson, University of Edinburgh, for contributions to the development of geographical studies in Canada ; Back Grant, to A. T. Grove, University of Cambridge, for geomorphological studies in Northern Africa ; Cuthbert Peek Grant, to G. F. Reid, directorate of Overseas Surveys, for contributions to Antarctic surveying; Gill Memorial, to Joyce M. Lambert, University of Southampton, for research in the origin of the Broads; and Mrs. Patrick Ness Award, to R. J. Adie, University of Birmingham, for contributions to Antarctic geology.

\section{Institute of Metals Awards}

THE Institute of Metals has made the following awards: Institute of Metals (Platinum) Medal for 1960 , to Prof. Robert Franklin Mehl (head of the Department of Metallurgical Engineering, Carnegie
Institute of Technology, Pittsburgh) in recognition of his outstanding contributions to the science of metals and to metallurgical education; Rosenhain Medal for 1960 , to Prof. Norman James Petch (William Cochrane professor of metallurgy, King's College, Newcastle on Tyne) in recognition of his outstanding contributions in the field of physical metallurgy; W. H.A. Robertson Medal and Premium, for 1959, to Dr. Maurice Cook and Mr. E. Swainson (formerly chairman and assistant manager, Technical Department, respectively, Imperial Chemical Industries, Ltd., Metals Division, Witton, Birmingham) for a paper on "Arc Melting of Reactive and Refractory Metals", published in the Journal of the Institute of Metals, 87, 161 (1958-59).

\section{Wolfson Research Professorship of the Royal Society}

THE Council of the Royal Society has accepted with thanks the offer of the Isaac Wolfson Foundation to create a special fund of $£ 200,000$ for the endowment of a research professorship, to be known as the Wolfson Research Professorship of the Royal Society. The chair is to be held by a distinguished British scientist, who will devote the whole of his time to research in such fields as the President and Council of the Royal Society may from time to time think appropriate. The first holder, who has yet to be appointed, will work in the physical sciences or their borderlines with biology. The financial provision allows for adequate scientific and technical assistance for the Wolfson research professor.

\section{Herald Reactor at Aldermaston}

THE research reactor Herald of the United Kingdom Atomic Energy Authority started operation on March 7 at the Atomic Weapons Research Establishment, Aldermaston. It will be used for nuclear research work requiring intense neutron beams and for irradiation-damage studies on reactor materials. Herald is a light water-moderated and -cooled tanktype thermal reactor designed to operate continuously at $5 \mathrm{MW}$. The core of the reactor is in the form of thin plates of enriched uranium-aluminium alloy suitably spaced in water. A high flux density of thermal and fast neutrons of the order of $10^{14}$ neutrons per $\mathrm{cm} .^{2}$ will be achieved. The reactor was built for the Atomic Energy Authority by the Associated Electrical Industries/John Thompson Nuclear Energy Co., Ltd., and is an adaptation of the Merlin reactor.

\section{U.S. Council for the Advancement of Science Writing}

A U.S. Council for the Advancement of Science Writing has been established. Its purpose is to stimulate an increase in the quantity and quality of science news that is carried in all media of mass communications - newspapers, television, radio, magazines and books for the general public. It plans to do this by fostering research and training in science journalism, and by sponsoring discussions and seminars on science writing throughout the United States. The aim is to heighten the public's understanding and appreciation of the scientific enterprise. The Council, a non-profit corporation registered in the State of New York, was set up through the efforts of the National Association of Science Writers. Among those elected to the Council at its first meeting in New York City were: President, Earl 